\title{
Article \\ Description Relationship between Urban Space and Quality of Urban Life. A Geographical Approach
}

\author{
František Petrovič ${ }^{1, *(D)}$ and František Murgaš ${ }^{2}$ (D) \\ 1 Department of Ecology and Environmental Sciences, Constantine the Philosopher University in Nitra, \\ 94901 Nitra, Slovakia \\ 2 Department of Geography, Technical University in Liberec, 46117 Liberec, Czech Republic; fmtren@gmail.com \\ * Correspondence: fpetrovic@ukf.sk
}

check for updates

Citation: Petrovič, F.; Murgaš, F. Description Relationship between Urban Space and Quality of Urban Life. A Geographical Approach. Land 2021, 10, 1337. https://doi.org/ 10.3390/land10121337

Academic Editor:

Anna Winiarczyk-Raźniak

Received: 30 October 2021

Accepted: 1 December 2021

Published: 4 December 2021

Publisher's Note: MDPI stays neutral with regard to jurisdictional claims in published maps and institutional affiliations.

Copyright: (c) 2021 by the authors. Licensee MDPI, Basel, Switzerland. This article is an open access article distributed under the terms and conditions of the Creative Commons Attribution (CC BY) license (https:/ / creativecommons.org/licenses/by/ $4.0 /)$.

\begin{abstract}
The examination of the relationship between the construct of urban space and the construct of the quality of urban life is based on the knowledge that their common element is real physical space, i.e., the place. If the examination of the relationship between the two constructs is to be meaningful, then both must be on the same comparative basis—that means quality. The paper consists of two parts-the first part, which is theoretical, takes the form of conceptualization of urban space and the quality of urban life, including the identification of elements which affect them. The result of conceptualizing urban space into a qualitative form is liveability. The result of conceptualizing the quality of urban life is a holistic quality of life in the city, containing two domains-subjective and objective. The second part of the paper is the application of both constructs in a concrete form, based on measuring the values of these indicators and also the analysis of the results. The measurement takes the form of liveability on the one hand and of satisfaction with the place and/or satisfaction with the quality of urban life on the other hand.
\end{abstract}

Keywords: city; urban space; quality of urban life; liveability; Global Liveability Index; quality of place

\section{Introduction}

In this paper we deal with the construct of urban space (US), the construct of the quality of urban life (QoUL), and their relationship. We explore the US, place, city, and other constructs as elements of physical space; we do not deal with virtual space and primarily also not with social space. From the US, we focused on its quality. The description relationship between the US and QoUL is based on the knowledge of the existence of their common element, which is physical space-in the US called "place", in QoUL called various terms (objective well-being, place) but always related to place. US, especially public US, is a frequently used but it is a vague term in the urban context. Therefore, we identify it with place due to the focus of the paper. This will allow the exploration of the quality of the US, its quantification, and thus create an opportunity to describe its relationship with QoUL. The paper consists of two parts. The theoretical part is focused on the analysis of the urban space/place, QoUL, and the factors that affect them-the city and liveability. In the second part, we focus on US and QoUL measurements, and based on measurements we formulate our findings.

The aim of the paper is to explore the relationship between the US and QoUL, to transform the US into a measurable form, to quantify it in a concrete form, and thus to provide decision-makers in public policy with a valid basis for decision-making.

Exploring the description relationship between urban space and the quality of urban life is not an abstract scientific problem; its findings will contribute not only to urban and geographical knowledge but also to the improvement of urban planning and public policy in general. A "fundamental assumption underlying many approaches to planning and design is that places may be designed to enhance the quality of people's lives" [1]. 


\subsection{Theoretical Background}

The key terms of our paper are city, US, and QoUL. The US can be divided into several urban areas, but it can also consist of only one urban area. Researchers deal mainly with public spaces and open spaces. The US has two dimensions: subjective, called "sense of place", and objective, called "environment". QoUL also has two domains: subjective, called well-being, and objective, called site quality. From a spatial point of view, QoUL focuses on parts of the city, the city as a whole, or a large city with its surroundings, forming a metropolitan area.

The basic physical point of our paper is the city "as a whole", in which the US and QoUL overlap. If the investigator of this overlap is to bring valid results, it is necessary to describe not only the US and QoUL but also the elements that affect them.

\subsubsection{City}

Cities are among the oldest material artifacts in human history. For thousands of years, they have been and still are a place where the key drivers of human thinking, inventions, art, and creativity operate. As Glaeser states in his book Triumph of the City, ancient Athens or renaissance Florence were at the forefront of development [2]. Today, this role has moved to global cities of the highest category and selected cities in Silicon Valley-type regions.

The study of cities can begin with the questions: what is a city and how can a city be defined? In British English, there is a distinction between the terms of city and town, and this distinction is also used by UN Habitat and other international organizations [3]. In the paper, we do not distinguish these terms and we only use the term city. For millennia, the city was a seat which was separated by walls from its surroundings. This means that it was spatially clearly identified. At present, the population criterion or the legal criterion according to which a city is a seat included in the list of cities by law is used to determine which seat is considered a city. Different countries use different populations to determine whether a seat is a city: Denmark 200 inhabitants; Argentina 2000; India 5000; Japan 50,000; and China 100,000 [3]. According to Caves [4], the city "can be defined as a permanent and densely settled place with administratively defined boundaries whose members work primarily on non-agricultural tasks". O'Sullivan [5], in the eighth edition of his Urban Economics, states the terms 'urban area', 'metropolitan area', and 'city'. These three terms will be used interchangeably. He defines the city in the USA as "an urban area as a geographical area that contains a large number of people in a relatively small area. In other words, an urban area has a population density that is high relative to the density of the surrounding area" [5]. The U.S. Census Bureau considers an urban area "a densely settled geographical area with a minimum population of 2500 people and a minimum density of 500 people per square mile ... Metropolitan area is: A core area with a substantial population nucleus, together with adjacent communities that are integrated, in an economic sense, with the core area. To qualify as a metropolitan area, the minimum population is 50,000 people" [5].

Extreme differences in the definition of cities in individual countries have led to difficulties in comparing cities. Therefore, in 2020, the UN Statistical Commission adopted a joint proposal of the European Commission and other major international organizations: A recommendation on the method to delineate cities, urban and rural areas for international statistical comparisons. It is based on the Degree of Urbanization, which combines population size and population density. The traditional division of territory into towns and villages is replaced by three classes- 'cities', 'towns and semi-dense areas', and 'rural areas'. Cities have 50,000 and more inhabitants, towns 5000-49,999 inhabitants, and villages 500-4999 inhabitants [6]. In the Czech Republic, which is the subject of our focus, the criterion is a population of 5000, but many cities have a lower population (which is the result of historical development). At the same time, there are seats that have a population of more than 5000 but are not recognized as cities. Cities are currently generally not spatially identified, mainly due to urban sprawl and other urban processes. 
Currently, the number of people living in cities has exceeded 50 percent of the global population [7], with a forecast of 66 [8] to 75 percent in 2050 [9]. The fastest growth of urbanization will be recorded in low-to-middle-income countries [8]. In Europe, 75 percent of the population lives in cities, and in some countries such as Belgium, Malta, the Netherlands, Iceland, and Luxembourg it is more than 90 percent. The country with the lowest urban population is Moldova with 43 percent. In 2050, the European average urbanization rate will be more than 80 percent [10]. As a result, the current rate of urbanization will increase only slowly, with some countries experiencing a slight decline in urbanization.

In 1966, the following seven global cities or urbanized regions were considered the most important: London, Paris, Moscow, New York, Tokyo, the German region Rhine-Ruhr, and the Dutch city region of Randstad [11].

At the turn of the millennium, socio-economic development, including urban development, was influenced by accelerating globalization, to which geographers from the Globalization and World Cities Research Network (GaWC) responded by identifying the structure of global cities with Alpha, Beta, and Gamma categories [12]. "Globality" of cities is measured by several rankings, which jointly identify New York, London, Tokyo, and Paris in the first four places. In the Global Cities Index for 2020, Moscow ranks 20th among the 25 most important cities as the only city in Central and Eastern Europe [13]. After the disintegration of the bipolar world and the accompanying political and economic changes, the cities of Central Europe also became involved in the global development of cities, of which Warsaw and Prague have the most important positions on an international scale. The position of these two cities confirmed their inclusion in the highest category Alpha, subcategory Alpha [14]. Development of Central European cities in EU member states in terms of the structure of their driving forces is explored by Raźniak et al. [15].

The processes related to the development of current post-industrial cities are very differentiated depending on which country we analyze. In developed countries, the processes of urbanization, suburbanization, deurbanization, shrinking city, and urban sprawl are taking place simultaneously. According to Barreira et al. [16], population decline in some types of cities is occurring all around the world. The shrinking city process, with an impact on cities and their US, is the product of urbanization caused by industrialization as well as urban population growth. Just as industrialization began in England, the processes of deindustrialization and subsequent shrinkage of cities began in this country. The depopulation of cities as a result of migration is reflected in the growing vacancy of buildings, streets, and entire neighborhoods. This has a strong impact on the people who remain in the shrinking city. Between the years 1970 and 2014, 10\% of cities worldwide lost population, compared to $40 \%$ in Europe, the United States, and Canada between the years 1990 and 2000. After the regime change in 1990, shrinking city processes also manifested themselves in the countries of the former Soviet Union and the countries of Central and Eastern Europe, including the Czech Republic. The declining processes of city populations affected more than $50 \%$ of cities in the Czech Republic, the Baltic countries, and the Balkans. In connection with the shrinking city process, it is important to state that it is not linear in time or space, and it does not apply to all cities in a given country or to all cities in a given size category in one country. In the Czech Republic, this is illustrated by the decline in the population of some regional cities. The problem is that research is dedicated to the shrinking city processes of cities with more than 50,000 inhabitants, but Europe is dominated by cities with 10,000 to 50,000 inhabitants [17].

Urban development is fundamentally affected by one of the key demographic processes, which is fertility. A fall in the birth rate below the survival rate of 2.1 children per woman will have serious social, economic, and political consequences. At the beginning of the 21st century, the UN forecasted population declines in Estonia, Latvia, Bulgaria, the Czech Republic, Ukraine, Hungary, Belgium, Spain, and Italy [18]. At present, population decline affects all European countries. The population of the Czech Republic is not declining, because the decline of the Czech population was replaced by emigrants from Central and Eastern European countries, especially from Ukraine, until the outbreak of the 
COVID-19 pandemic. The complexity of urban development in the countries of Central and Eastern Europe is currently illustrated by Prague. Over the recent decades, the Czech inhabitants of Prague have moved to the surrounding districts of Prague-East and PragueWest, resulting in the position of the Prague agglomeration as the only population-growing region of the Czech Republic. However, the population of Prague is not declining, because the migration increase of foreigners is higher every year than the migration decrease and the natural decrease of the Czechs. In 2020, 228,000 foreigners lived in Prague, representing $17 \%$ of its population and $36 \%$ of foreigners throughout the Czech Republic. The share of foreigners in Prague is growing faster than the share of foreigners in the whole of the Czech Republic (Czech statistical office 2021). Regardless of the growth or decline of urban populations in developed countries, the quality of life of their inhabitants is improving. In developing countries, there is an uncontrollable increase in the urban population due to the migration of people from the countryside to the cities, especially the largest ones. Some governments are responding to this trend by supporting the development of smaller towns. Rezvani et al. [19] illustrate this with the example of the Iranian city of Noorabad.

We answer the question "what is a city?" as follows: The present city is a complex system of social, economic, and environmental ties of people living usually in large numbers and permanently in one place.

\subsubsection{Urban Space/Place}

In urban studies, the term "space" is used, both in a general context, e.g., "social space" or "public space", as well as in relation to a specific space, which may be a street or a district of a city. In terms of our paper focus, we consider the US to be a place.

The US is an aspect of urbanization [20]; it is a spatial part of the city that is usually not defined administratively. The terminology related to the phenomenon of cities is not uniform and this also applies to the US. In addition to this term, the term "urban area" is also used [21]. Defining the US is difficult [20]. The reason is that none of the components that make up the US - neither the city nor the space- - has a fixed definition. According to the US definition, it "refers to several urban areas and their related multicentric municipalities forming a whole in a single stretch" [22].

The conditions for living in the city are formed by technical and transport networks, which together with cultural, medical, educational, sports facilities, and parks form an environment-an objective dimension of the US. According to Adams [23], it is an objective quality. This environment represents the external circumstances for the social life, work, study, culture, and leisure of the city's inhabitants, forming the sense of place; the subjective dimension of the US. According to Adams [23], is it a subjective quality.

As mentioned above, the element in which the US and QoUL overlap is the place. The quality of the place is considered by Murgaš and Klobučník [24] to be an objective dimension of quality of life. According to Marans [25], there is considerable evidence of the fact that "place matters". A place is any locality on the earth's surface, being urban, rural, or natural. In the urban sense, the place is part of the US. At the same time, the city is the sum of neighboring places. Geographers consider place to be one of the five key themes of geography [26]. Place consists of three components: location, locale, and a sense of place. Location is the position of a particular point on the surface of the earth. Locale is the physical setting for relationships between people, and sense of place is the emotions someone attaches to an area based on their experiences. "Place, here, is defined as a portion of space that has accumulated particular meanings at both the level of the individual and the social" states Cresswell [27]. However, Ziółkowska-Weiss [7] states: "the very definition of a place that can be considered sustainable, open and functional is still not clarified".

\subsubsection{Liveability}

We briefly characterized the city, the US, the place, and its operations. The term "liveability" represents a comprehensive expression of the conditions of a place to live in it. The Cambridge English Dictionary (online) defines liveability as follows: "the degree to which 
a place is suitable or good for living in". According to the architectural and consulting company Ramboll [28], "Liveability describes the frame conditions of a decent life for all inhabitants of cities, regions and communities including their physical and mental wellbeing". In his famous fourfold matrix of four qualities of life, Veenhoven [29] distinguishes "livability of environment" (he also uses the term liveability) and "life-ability of the person". It is clear from this that the term livability is related to the environment and life-ability to man. Livability, synonymous with habitability, is the result of a combination of life chances and outer qualities. Veenhoven [30] defines it as follows: "Livability is the degree to which a living environment fits the adaptive repertoire of a species. Applied to human society, it denotes the fit of institutional arrangements with human needs and capacities."

Liveability is investigated by Okulicz-Kozaryn [10], who identifies it with the objective dimension of quality of life. It follows that liveability can be seen in relation not only to the city but also to any place. The correlation between the subjective dimension (well-being) and liveability has a value of 0.40 . Given the focus of our paper, we define liveability as the level of external conditions of a place for a good life.

\subsubsection{Quality of Urban Life}

The quality of life is divided into urban and rural according to the place where the people we are interested in live. Nuvolati [31] defines urban quality of life as follows: "quality of urban life regards the living conditions in urban areas and mainly in the cities". In our opinion, QoUL, like QoL, is holistic, and therefore contains two dimensions. In addition to living conditions representing an objective dimension, it also includes satisfaction with life in the city. We therefore define QoUL as an expression of satisfaction with life lived in the city. The key position of cities in today's world also corresponds to the number of authors investigating the quality of urban life $[1,9,19,25,31-36]$. The authors focused on the quality of rural life are less common $[37,38]$. The study of QoUL began in the 1960s [25]. QoUL, like quality of life, is often identified with well-being, satisfaction with life, or happiness.

QoUL is an expression of the degree of satisfaction of the inhabitants with their life in a given city, either on the Cantril numerical scale $0-10$ or on 5- or 7-degree word Likert scale. In developed countries, life satisfaction is above average and is therefore referred to as well-being. QoUL acts as a significant factor in the city's attractiveness from a migratory point of view or as a factor influencing city growth, as analyzed by Royuela et al. [21].

\section{Methods and Results}

We conceptualized US and QoUL into a form that allows them to be measured; QoUL is measured by Ira and Andráško [39], Lora and Powell [40], and Tiran [41]. Murgaš and Klobučník [42] in their paper investigated QoUL of Czech cities according to size categories (Table 1) and QoUL regional cities (Table 2).

Table 1 shows that the largest Czech cities of Prague, Brno, Ostrava, Pilsen, Liberec, and Olomouc have the highest QoUL values. Table 2 includes the QoUL values and the ranking of regional cities.

The sharp deterioration of QoUL values in Ústí nad Labem, Karlovy Vary, and Ostrava in comparison with other regional cities comes as a surprise. In Ostrava, the low level of QoUL goes hand in hand with the shrinking city process. Ostrava was the industrial center of the state with mining and heavy industry, and in 1990 it had population of 331,000. After the fall of the previous regime, these industries were hit by a steep decline, and in 2020 the population fell to 285,000 . According to geographers from the University of Ostrava, the shrinking city process in Ostrava had a mild course, incomparable with cities such as Liverpool or Leipzig, where the population dropped by hundreds of thousands. Nevertheless, in some US of Ostrava 'socially excluded localities' were created [43], and Murgaš and Drápela [36] explored QoUL in socially excluded localities. 
Table 1. Values of quality of urban life in group size of Czech cities [44].

\begin{tabular}{cc}
\hline Population & Average Value Quality of Life \\
\hline Municipalities & 5.81 \\
Cities & 5.14 \\
less than 2000 & 4.63 \\
$2001-5000$ & 5.15 \\
$5001-10,000$ & 5.33 \\
$10,001-20,000$ & 5.18 \\
$20,001-50,000$ & 5.20 \\
$50,001-100,000$ & 5.17 \\
more than 100,000 & 6.77 \\
\hline
\end{tabular}

Table 2. QoUL index and ranking of regional cities from all 6251 Czech municipalities [44].

\begin{tabular}{ccc}
\hline City & Index Quality of Life & $\begin{array}{c}\text { Ranking of the City from All } \\
\text { Czech Municipalities }\end{array}$ \\
\hline Brno & 7.74 & 12 \\
Hradec Králové & 7.63 & 24 \\
Jihlava & 7.39 & 70 \\
Praha & 7.26 & 123 \\
České Budějovice & 7.30 & 228 \\
Zlín & 6.96 & 289 \\
Olomouc & 6.51 & 740 \\
Liberec & 6.41 & 901 \\
Plzeň & 6.36 & 991 \\
Pardubice & 6.26 & 1155 \\
Ústí nad Labem & 4.68 & 4628 \\
Karlovy Vary & 4.57 & 4797 \\
Ostrava & 4.17 & 6327 \\
\hline
\end{tabular}

However, the regional city of Karlovy Vary, the most important Czech spa center with a long tradition, in which there is almost no industry, also has a very low QoUL value. The city was included in the UNESCO list in 2020. Both cities with completely different structural problems have similarly low QoUL values. We pay attention to the differentiation of QoUL in Czech cities in an effort to emphasize the need for a comprehensive approach to QoUL.

In the introduction of this paper, we formulated its intention to provide valid data for policy-makers in urban planning. Khorrami et al. [44] used electronic databases to assess 3599 papers of investigated liveability, of which 67 measured it. The result is the identification of the most important domains: (i) economic, (ii) environmental, (iii) institutional, (iv) social, and (v) domains of governance (policy).

Psatha et al. [32] proposed 12 QoUL domains together with their specific indicators, which can be further specified (Table 3). Their design is a common top-down solution approach when someone determines what constitutes QoUL in our case. The opposite approach-"bottom-up" - would in the European conditions mean asking the inhabitants of European cities which indicators or domains they consider most important for QoUL. Subsequently, in the first step would necessitate compiling a binding QoUL questionnaire according to size categories of cities. The second step would include regular identification of QoUL similarly to the European Social Survey questionnaires. The "bottom-up" approach will provide more valid data than the "top-down" approach.

QoUL or liveability is measured worldwide in cities of all size categories, from small cities or suburbs [45] to metropolitan areas of large cities [46], with the various indicators used. Table 4 shows the domains (in some cases these are indicators) of selected liveability and QoUL measurements. 
Table 3. Design of domains and QoUL indicators for European cities [32].

\begin{tabular}{|c|c|c|c|c|c|c|c|}
\hline \multicolumn{4}{|c|}{ Economic Environment } & \multicolumn{4}{|c|}{ Social Environment } \\
\hline \multicolumn{4}{|c|}{$\begin{array}{l}\text { Employment opportunities, employment structure, average income and } \\
\text { income distribution, living costs, etc. }\end{array}$} & \multicolumn{4}{|c|}{ Crime, social inequalities, social exclusion, networks and infrastructure } \\
\hline \multicolumn{4}{|c|}{ Natural environment } & \multicolumn{4}{|c|}{ Built environment } \\
\hline \multicolumn{4}{|c|}{$\begin{array}{c}\text { Air quality, water resources, waste management, suburban natural } \\
\text { environment, accessibility to areas of natural beauty, weather and } \\
\text { climate }\end{array}$} & \multicolumn{4}{|c|}{$\begin{array}{l}\text { Building density, housing conditions, public monumental buildings, } \\
\text { building stocks, neighborhoods, etc. }\end{array}$} \\
\hline \multicolumn{4}{|c|}{ Urban and suburban green spaces } & \multicolumn{4}{|c|}{ Public spaces-Public buildings } \\
\hline \multicolumn{4}{|c|}{$\begin{array}{c}\text { Total area and rate per resident, conditions, allocation, accessibility, } \\
\text { usage, etc. }\end{array}$} & \multicolumn{4}{|c|}{$\begin{array}{l}\text { Area, quality, condition and maintenance, accessibility, visiting rates, } \\
\text { etc. }\end{array}$} \\
\hline \multicolumn{4}{|c|}{ Culture-Leisure } & \multicolumn{4}{|c|}{ Demographic data } \\
\hline \multicolumn{4}{|c|}{$\begin{array}{l}\text { Cultural resources, tourism infrastructure, recreation areas, leisure } \\
\text { activities, entertainment capabilities, cultural life, available choices }\end{array}$} & \multicolumn{4}{|c|}{ Marital and family status of adults, age rates, level of education } \\
\hline \multicolumn{4}{|c|}{ Education } & \multicolumn{4}{|c|}{ Healthcare } \\
\hline \multicolumn{4}{|c|}{$\begin{array}{l}\text { Education units, quality and maintenance, attendance per education } \\
\text { level, private schools etc. }\end{array}$} & \multicolumn{4}{|c|}{ Health services, accessibility, social welfare for the disadvantaged, etc. } \\
\hline \multicolumn{4}{|c|}{ Democratic institutions } & \multicolumn{4}{|c|}{ Traffic and transportation } \\
\hline \multicolumn{4}{|c|}{ Democratic regime, election of local government, voting rates, etc. } & \multicolumn{4}{|c|}{$\begin{array}{l}\text { Traffic conditions, parking spaces, efficiency of public transportation } \\
\text { and level of transportation services, accessibility of districts }\end{array}$} \\
\hline $\begin{array}{l}\text { Murgaš and } \\
\text { Klobučník [42] }\end{array}$ & $\begin{array}{l}\text { Rišová and } \\
\text { Pouš [47] }\end{array}$ & Gallup [48] & Badland & et al. [46] & Khorrami et al. [44] & $\begin{array}{l}\text { Economist } \\
\text { Intelligence } \\
\text { Unit [49] }\end{array}$ & $\underset{\text { Ziółkowska-Weiss }}{ }$ \\
\hline $\begin{array}{l}\text { Gold Standard } \\
\text { Quality of Life }\end{array}$ & Urban Facilities & $\begin{array}{l}\text { Gallup-Sharecare } \\
\text { Well-Being Index }\end{array}$ & $\begin{array}{r}\text { Urban } \mathbf{L} \\
\text { In }\end{array}$ & $\begin{array}{l}\text { iveability } \\
\text { dex }\end{array}$ & $\begin{array}{l}\text { Measuring Urban } \\
\text { Liveability }\end{array}$ & $\begin{array}{l}\text { Global Liveability } \\
\text { Index }\end{array}$ & $\begin{array}{l}\text { Quality of Urban } \\
\text { Space in Greater } \\
\text { Toronto Area }\end{array}$ \\
\hline Suicides & $\begin{array}{l}\text { Public sport } \\
\text { facilities }\end{array}$ & Sense of purpose & Empl & yment & Economic & Stability & Housing \\
\hline $\begin{array}{l}\text { Life expectancy at } \\
\text { birth-males }\end{array}$ & Bus stops & Social relationship & Food en & ironment & Environment & Healthcare & Work \\
\hline $\begin{array}{l}\text { Life expectancy at } \\
\text { birth-females }\end{array}$ & Parks & Financial security & Но & asing & Institutions & Education & Transport \\
\hline Mortality & Primary schools & $\begin{array}{l}\text { Relationship to } \\
\text { community }\end{array}$ & Public o & pen space & Society & $\begin{array}{l}\text { Culture and } \\
\text { environment }\end{array}$ & $\begin{array}{c}\text { Natural } \\
\text { environment }\end{array}$ \\
\hline Birth rate & Nursery schools & Physical health & Social inf & rastructure & Governance & Infrastructure & $\begin{array}{l}\text { Tourism, leisure, } \\
\text { and relaxation }\end{array}$ \\
\hline $\begin{array}{l}\text { Divorce rate } \\
\text { University }\end{array}$ & $\begin{array}{c}\text { Public libraries } \\
\text { Pharmacies }\end{array}$ & & $\begin{array}{r}\text { Trar } \\
\text { Walk }\end{array}$ & $\begin{array}{l}\text { sport } \\
\text { ability }\end{array}$ & & & \\
\hline $\begin{array}{c}\text { education } \\
\text { Unemployment } \\
\text { Emission balance } \\
\text { Generativity }\end{array}$ & $\begin{array}{c}\text { ATMs } \\
\text { Bank branches } \\
\text { General } \\
\text { practitioners } \\
\text { Post office branches } \\
\text { Playgrounds } \\
\text { Grocery stores }\end{array}$ & & & & & & \\
\hline
\end{tabular}

An overview of the domains and indicators used to measure liveability and QoUL shows that they are similar, but not the same. The problem of unifying-but not unification (The choice of liveability and QoUL indicators is determined by their availability for individual size categories of cities and also by cultural contexts. These were reflected in the preparation of materials for planning of the increasing liveability in Bangkok, drawing on the experience of Australian researchers who developed such material for Melbourne. Access to temples and cultural opportunities as a minor element of social infrastructure in Melbourne has been shown to be an important element of social infrastructure in Bangkok [8].) of indicators can be solved by disclosure of the recommended indicators by a respected international entity. This was the case with the WHO definition of quality of life.

Liveability is not only an academic issue but also has an economic dimension, among other things, in the form of real estate prices, which is why economic publishing houses 
also focus on it. The Economist Intelligence Unit (EIU) publishes the Global Liveability Index, which evaluates 140 cities around the world (Table 4). It uses the following as indicators: (i) stability, (ii) healthcare, (iii) education, (iv) culture and environment, and (v) infrastructure. Table 5 shows that the liveability in the 140 most important cities in the world is relatively stable. In 2015-2017, the changes at the top of the ranking were minimal, and in 2018-2019 Melbourne replaced Vienna at the very top, with some Japanese cities and Copenhagen replacing some Australian cities, but overall, it can be stated that the changes in the top seven were small. However, the COVID-19 pandemic caused major changes in ranking in 2021, with the average liveability falling by six points. Vienna dropped from the list of 10 of the world's most liveable cities, as did the Canadian cities of Vancouver, Toronto, and Calgary. The top ten cities in the index for 2021 include six cities from New Zealand and Australia, and another two locations also belong to cities from the islands of Japan. Only the Swiss cities of Zurich and Geneva represent inland countries.

Table 5. Ranking of the most successful cities in the Global Liveability Index in 2015-2021 [50-54].

\begin{tabular}{|c|c|c|c|c|c|c|}
\hline \multicolumn{7}{|c|}{ Ranking the World's Most Liveable Cities 2015-2021 } \\
\hline City & 2015 & 2016 & 2017 & 2018 & 2019 & 2021 \\
\hline Melbourne & 1 & 1 & 1 & 2 & 2 & $8-9$ \\
\hline Vienna & 2 & 2 & 2 & 1 & 1 & \\
\hline Vancouver & 3 & 3 & 3 & 6 & 6 & \\
\hline Toronto & 4 & 4 & 4 & $7-8$ & $7-8$ & \\
\hline Adelaide & $5-6$ & $5-6$ & $5-6$ & 10 & 10 & 3 \\
\hline Calgary & $5-6$ & $5-6$ & $5-6$ & 4 & 5 & \\
\hline Sydney & 7 & & & 5 & 3 & \\
\hline Perth & 8 & 7 & 7 & & & 6 \\
\hline Auckland & 9 & 8 & 8 & & & 1 \\
\hline Helsinki & $10-11$ & 9 & 9 & & & \\
\hline Zurich & $10-11$ & & & & & 7 \\
\hline Hamburg & & 10 & 10 & & & \\
\hline Osaka & & & & 3 & 4 & 2 \\
\hline Tokyo & & & & $7-8$ & $7-8$ & $4-5$ \\
\hline Copenhagen & & & & 9 & 9 & \\
\hline Wellington & & & & & & $4-5$ \\
\hline Geneva & & & & & & $8-9$ \\
\hline Brisbane & & & & & & 10 \\
\hline
\end{tabular}

The success of cities from island countries shows the effectiveness of using the possibility of strict border controls and the ability of policy-makers to respond to the development of a pandemic [49].

German Hamburg took the lead in the "biggest movers down the ranking", as it fell by 34 places to place 47 in the ranking for 2021 (Table 5). Table 6 shows the list of the cities that managed to increase their liveability during the pandemic-Honolulu managed to do so by 46 places.

Table 6. Biggest movers down the ranking in the past six months 2021 [49].

\begin{tabular}{ccccc}
\hline City & Index & Rank & Rank Move & Index Move \\
\hline Hamburg & 81.9 & 47 & -34 & -8.5 \\
Frankfurt & 82.8 & 39 & -29 & -8.5 \\
Dusseldorf & 80.2 & 50 & -28 & -8.3 \\
Prague & 71.2 & 72 & -27 & -9.6 \\
Dublin & 80.1 & 51 & -22 & -6.4 \\
\hline
\end{tabular}

The comparison of Tables 6 and 7 show a surprising finding —-the highest increase and decrease in their liveability was achieved by major cities in developed countries. 
Table 7. Biggest movers up the ranking in the past six months 2021 [49].

\begin{tabular}{ccccc}
\hline City & Index & Rank & Rank Move & Index Move \\
\hline Honolulu & 90.6 & 14 & 46 & 14.2 \\
Houston & 84.0 & 31 & 31 & 7.8 \\
Madrid & 86.8 & 19 & 25 & 5.5 \\
Miami & 84.3 & 28 & 24 & 5.6 \\
Barcelona & 88.3 & 16 & 22 & 5.5 \\
\hline
\end{tabular}

We focus more closely on the EIU index in more detail for two reasons. The first is that liveability values are relatively stable and high in the most important cities in the world. The second reason is the strong impact of the COVID-19 pandemic on the measurement of liveability in 2021. In addition to other effects, this impact meant the justification of the rejection "death of geography" [55]. The extinction of geography in the form of the loss of the meaning of physical space was expected in connection with the transfer of social and economic activities from real to virtual space and the expansion of globalization. Another finding brought about by the pandemic on liveability measurement was the return of the geographical location. At the time of the explosion of globalization, the term "geographical location" seemed to be forgotten, but cities from island countries are at the top of the liveability ranking of the most important cities in the world.

Forbes made the unusual measurement of The World's Best and Worst Cities to Live with its Expat City Ranking 2020. Each year, the pool of the four million expat community determines the ranking of Best and Worst Cities to Live. The pool includes foreigners living in the given cities for a long periods of time. In 2020, 15,000 expats determined the ranking shown in Table 8. Overall, 66 sites were evaluated [56]. This measurement expresses the "satisfaction with place".

Table 8. The World's Best and Worst Cities to Live (adapted from Bloom Begley [57]).

\begin{tabular}{|c|c|c|c|c|c|}
\hline \multicolumn{3}{|c|}{ The World's Best Cities to Live } & \multicolumn{3}{|c|}{ The World's Worst Cities to Live } \\
\hline Rank & City & Country & Rank & City & Country \\
\hline 1. & Valencia & Spain & 1. & Salmiya & Kuwait \\
\hline 2. & Alicante & Spain & 2. & Rome & Italy \\
\hline 3. & Lisbon & Portugal & 3. & Seoul & South Korea \\
\hline 4. & Panama City & Panama & 4. & Milan & Italy \\
\hline 5. & Singapore & Singapore & 5. & Nairobi & Kenya \\
\hline 6. & Malaga & Spain & 6. & Paris & France \\
\hline 7. & Buenos Aires & Argentina & 7. & Johannesburg & South Africa \\
\hline 8. & $\begin{array}{c}\text { Kuala } \\
\text { Lumpur }\end{array}$ & Malaysia & 8. & $\begin{array}{l}\text { Santiago de } \\
\text { Chile }\end{array}$ & Chile \\
\hline 9. & Madrid & Spain & 9. & Dublin & Ireland \\
\hline 10. & Abu Dhabi & United Arab Emir. & 10. & Hong Kong & Hong Kong SAR \\
\hline
\end{tabular}

In QoUL face-to-face measurements, individuals express satisfaction with life, or satisfaction with place, happiness, and other variables on either the numerical Cantril or verbal Likert scale. The resulting QoUL is the average of these values. In the Forbes measurement, expats determine the best and worst city for life, with the result being the sum of the best or worst rankings. Spanish cities are very well placed among the best cities to live in, and together with Lisbon in Portugal, they make up half of the top ten. On the other hand, Rome, Milan, and Paris, the world-famous "dolce vita" or "savoir vivre" centers, which are associated by tourists with cuisine and wine, and fashion and monuments of the highest quality are among the worst cities to live. Rome is the second worst city in the world. Brulé and Veenhoven [57] compared the quality of life in European Nordic and Romanesque countries. Denmark, the Netherlands, and Sweden had higher values not only in quality of life but also in other variables related to quality of life than France, Italy, and Spain. So why are the four Spanish cities on the list of the top ten places 
to live and not among the worst cities, along with Rome, Milan, and Paris-“"as they should be"? We point this out because in such a complex and multidimensional concept as quality of life, the measured values are often different "than they should be". Clarifying this issue is a big scientific challenge for researchers.

The following key findings are derived from the described liveability and QoUL measurements:

- Liveability is characterized in the dictionary as the "degree" in which the place is good for life [58], and according to another source it is "frame conditions" (Ramboll, online). Liveability in the form of a degree can be understood as liveability in the narrower sense, while liveability in the form of frame conditions is liveability in the broader sense.

- Liveability in the narrower sense represents the sum of technical equipment of the place, while liveability in the broader sense represents the sum of technical equipment, social relations, and environmental characteristics. The difference between a narrower and a broader understanding of liveability can be illustrated as follows: "school" is technical equipment, i.e., belongs to liveability in the narrower sense. "Education" is a characteristic for the population, so it is not technical equipment and therefore belongs to liveability in a broader sense.

- As with other social constructs, terminological chaos persists in the liveability construct. In addition to the term liveability, you can also see the term "urban facilities" [48] or the term "amenities" [59].

- The authors of the paper do not know about the measurement of the liveability of Czech cities by scholars. Therefore, it is not possible to compare liveability and QoUL, based on measuring life satisfaction on a scale of $0-10$.

- The relationship between the US and QoUL in a particular city is affected by whether or not the shrinking city process works. Although, in the Czech Republic, the accompanying phenomena of this process are not as significant as in cities such as Liverpool or Leipzig, in some US of some cities, e.g., Ostrava, it led to the transformation of US into socially excluded localities. In relation to QoUL in these localities, [36] report unexpected findings.

- The most important finding is the recognition that liveability is an objective dimension of QoUL, i.e., quality of the place. This finding confirms the validity of the argument by Okulicz-Kozaryn [10]. At a time when new vague terms are emerging in the social sciences, such as "social quality" [60,61], "economic well-being" [62], and others, we see meaning not in producing new vague terms but in the development of epistemology of already established constructs.

\section{Conclusions}

In the paper, we focused on the city, its US, and the QoUL of its inhabitants. The objective of the paper was formulated as follows: to explore the relationship between the US and QoUL, the transformation of the US into a measurable form, and its quantification. The common element in which the US and QoUL overlap is the physical space, which has the form of a place. The first part of the paper analyzes the urban space/place, QoUL, and the factors that affect them-city, topophilia/topophobia, sense of place/placelessness, and liveability. The result comes in the form of an understanding of liveability as a comprehensive expression of the conditions of a place and life in it. The second part is focused on the measurement of liveability and QoUL, confirming the complexity of the quality-of-life construct. The key finding of paper is the recognition that liveability is an objective dimension of QoUL, i.e., quality of the place.

Further research needs to focus on two areas: (i) the development of QoUL epistemology, necessary for global urban growth, and (ii) the development of epistemology based on measuring both dimensions of QoUL, which confirms or refutes the key finding of our paper that liveability is the quality of place, and thus the objective dimension of QoUL. Confirmation of findings will give urban planners, urban geographers, and city authorities 
valid information for urban development. The rebuttal of findings will mean the need to continue to look for valid information resulting from the measurements.

Author Contributions: Conceptualization, F.P. and F.M.; Formal analysis, F.M.; Investigation, F.P. and F.M.; Methodology, F.P. and F.M.; Project administration, F.P.; Supervision, F.P.; Validation, F.M.; Writing-original draft, F.P. and F.M.; Writing—review \& editing, F.P. All authors have read and agreed to the published version of the manuscript.

Funding: This paper was prepared with support from the Ministry of Education of the Slovak Republic and the Slovak Academy of Science-grant number VEGA 1/0706/20.

Institutional Review Board Statement: Not applicable.

Informed Consent Statement: Not applicable.

Data Availability Statement: Not applicable.

Conflicts of Interest: The authors declare no conflict of interest.

\section{References}

1. Marans, W.R. Quality of Urban Life Studies: An Overview and Implications for Environment-Behaviour. Procedia-Soc. Behav. Sci. 2012, 35, 1-22. [CrossRef]

2. Glaeser, E. Triumph of the City; Pan Publishing: London, UK, 2012; pp. 1-338.

3. Dijkstra, L.; Hamilton, E.; Somik Lall, S.; Wahba, S. How Do We Define Cities, Towns, and Rural Areas? World Bank: Washington, DC, USA, 2020. Available online: https:/ /blogs.worldbank.org/sustainablecities/how-do-we-define-cities-towns-and-rural-areas (accessed on 20 August 2021).

4. Caves, R.W. Encyclopedia of the City; Routledge: Oxon, UK, 2004; pp. 1-594.

5. O’Sullivan, A. Urban Economics, 8th ed.; McGraw-Hill/Irvin: New York, NY, USA, 1996; p. 496.

6. Statistical Cimmission UN. A Recommendation on the Method to Delineate Cities, Urban and Rural Areas for International Statistical Comparisons. 2020. Available online: https://unstats.un.org/unsd/statcom/51st-session/documents/BG-Item3jRecommendation-E.pdf (accessed on 12 November 2021).

7. Ziółkowska-Weiss, K. Satisfaction with Selected Indicators of the Quality of Urban Space by Polonia in the Greater Toronto Area. Land 2021, 10, 778. [CrossRef]

8. Alderton, S.; Davern, M.; Nitvimol, K.; Butterworth, I.; Higgs, C.; Ryan, E.; Badland, H. What is the meaning of urban liveability for a city in a low-to-middle-income country? Contextualising liveability for Bangkok, Thailand. Glob. Health 2019, 15, 1-13. [CrossRef]

9. Milivojević, J.; Cvetic, T.; Kokic Arsic, A.; Nikolić, N.; Petronijević, M. Quality of Life in Cities-Research Aspect. In Proceedings of the 2nd International conference on Quality of Life, Kragujevac, Serbia, 8-10 June 2017; University of Kragujevac: Kragujevac, Serbia, 2017; pp. 101-111.

10. Okulicz-Kozaryn, A. City Life: Rankings (Livability) Versus Perceptions (Satisfaction). Soc. Indic. Res. 2013, 110, 433-451. [CrossRef]

11. Raźniak, P.; Dorocki, S.; Winiarczyk-Raźniak, A. Permanence of the economic potential of cities based on sector development. Chin. Geogr. Sci. 2017, 27, 123-136. [CrossRef]

12. Globalization and World Cities Research Network. The World According to GaWC. 2020. Available online: https://www.lboro. ac.uk/gawc/world2020t.html (accessed on 20 August 2021).

13. Taylor, P.J. Regionality in the world city network. Int. Soc. Sci. J. 2004, 56, 343-469. [CrossRef]

14. Kearney. Global Cities: New priorities for a new world. Copyright 2020 Kearney. Available online: https://www.kearney.com/ global-cities / 2020 (accessed on 1 August 2021).

15. Raźniak, P.; Dorocki, S.; Winiarczyk-Raźniak, A. Eastern European cities as command and control centers in a time of economic crisis. Acta Geogr. Slov. 2018, 58, 101-110. [CrossRef]

16. Barreira, A.P.; Agapito, D.; Panagopoulos, T.; Guimarães, M.H. Exploring residential satisfaction in shrinking cities: A deci-siontree approach. Urban Res. Pract. 2017, 10, 156-177.

17. Wolff, M.; Wiechmann, T. Urban growth and decline: Europe's shrinking cities in a comparative perspective 1990-2010. Eur. Urban Reg. Stud. 2017, 25, 122-139. [CrossRef]

18. Rieniets, T. Shrinking Cities: Causes and Effects of Urban Population Losses in the Twentieth Century. Nat. Cult. 2009, 4, 231-254. [CrossRef]

19. Rezvani, M.R.; Mansourian, H.; Sattari, H.M. Evaluating Quality of Life in Urban Areas. Case Study: Noorabad City, Iran. Soc. Indic. Res. 2012, 112, 203-220. [CrossRef]

20. Agiurre, A. Urban Space. In Blackwell Encyclopaedia of Sociology; Ritzer, G., Ed.; Wiley-Blackwell: Hoboken, NJ, USA, 2007; pp. 5146-5149. 
21. Royuela, V.; Moreno, R.; Vayá, E. Influence of Quality of Life on Urban Growth: A Case Study of Barcelona, Spain. Reg. Stud. 2010, 44, 551-567. [CrossRef]

22. Institute National De La Statistique et Des Études Économiques. Urban Area. 2016. Available online: https://www.insee.fr/en/ metadonnees/definition/c1074 (accessed on 6 September 2021).

23. Adams, M. Quality of Urban Spaces and Wellbeing. In Wellbeing and the Environment: Wellbeing: A Complete Reference Guide, 2nd ed.; Cooper, R., Burton, E., Cooper, C.L., Eds.; John Wiley \& Sons: Hoboken, NJ, USA, 2014; pp. 1-21.

24. Murgaš, F.; Klobučník, M. Does The Quality of a Place Affect Well-Being? Ecology 2016, 35, 224-239. [CrossRef]

25. Marans, W.R.; Stimson, R. Investigating Quality of Urban Life: Theory, Methods, and Empirical Research; Springer: Dordrecht, The Netherlands, 2011; pp. 1-456.

26. Rosenberg, M. The 5 Themes of Geography. 2019. Available online: https://www.thoughtco.com/five-themes-of-geography-14 35624 (accessed on 6 September 2021).

27. Cresswell, T. Place. Headword. In The SAGE Handbook of Human Geography; Lee, R., Castree, N., Kitchin, R., Lawson, V., Paasi, A., Philo, C., Radcliffe, S., Roberts, S.M., Withers, C.W.J., Eds.; SAGE Publications Ltd: New York, NY, USA, $2014 ;$ pp. 3-21.

28. Ramboll. Liveability Defined. Available online: https://ramboll.com/megatrend/liveable-cities-lab/liveability-defined (accessed on 11 August 2021).

29. Veenhoven, R. The Four Qualities of Life. Ordering concepts and measures of the good life. In Understanding Human Wellbeing; McGillivray, M., Clark, M., Eds.; United Nations University Press: Tokyo, Japan; New York, NY, USA; Paris, France, 2006; pp. 74-100.

30. Veenhoven, R. Livability Theory. In Encyclopaedia of Quality of Life and Well-Being Research; Michalos, A.C., Ed.; Springer: Dordrecht, The Netherlands, 2014; pp. 3645-3647.

31. Nuvolati, G. Urban Life, Quality of. In Encyclopedia of Quality of Life and Well-Being Research; Michalos, A.C., Ed.; Springer: Dordrecht, The Netherlands, 2014; pp. 1-7347.

32. Psatha, E.; Deffner, A.; Psycharis, Y. Defining the quality of urban life: Which Factors should be Considered? European Regional Science Association, 51st European Congress Barcelona. 2011. Available online: http://www-sre.wu.ac.at/ersa/ersaconfs/ersa1 1/e110830aFinal00785.pdf (accessed on 11 August 2021).

33. Wẹziak-Białowolska, D. Quality of life in cities-Empirical evidence in comparative European perspective. Cities 2016, 58, 87-96. [CrossRef]

34. Grifoni Cocci, R.; Sargolini, M.; D’Onofrio, R. Quality of Life in Urban Landscapes: In Search of a Decision Support System; Springer: Cham, Switzerland, 2018; pp. 1-399.

35. Murgaš, F.; Klobučník, M. Quality of life in the city, quality of urban life or well-being in the city: Conceptualization and case study. Ecology 2018, 37, 183-200. [CrossRef]

36. Murgaš, F; Drápela, E. Quality of Urban Life in Socially Excluded Communities of Liberec Region. Int. J. Community Well-Being 2020, 3, 323-339. [CrossRef]

37. Guardiola, J.; García-Muñoz, T. Subjective Well-Being and Basic Needs: Evidence from Rural Guatemala. 2009. Available online: https:/ / www.academia.edu/17042098/Subjective_well_being_and_basic_needs_Evidence_from_rural_Guatema-la? email_work_card=title (accessed on 24 August 2021).

38. Boncinelli, F.; Pagnotta, G.; Riccioli, F.; Casini, L. The determinants of quality of life in rural areas from a geographic per-spective: The case of Tuscany. Rev. Urban Reg. Dev. Stud. 2015, 27, 105-1217. [CrossRef]

39. Ira, V.; Andráško, I. Quality of life in the urban environment of Bratislava: Two time-spatial perspectives. Geogr. J. 2008, 60, 149-178.

40. Lora, E.; Powell, A. A New Way of Monitoring the Quality of Urban Life; IDB Working Paper Series, No. IDB-WP-272; Inter-American Development Bank (IDB): Washington, DC, USA, 2011; pp. 1-35.

41. Tiran, J. Measuring urban quality of life: Case study of Ljubljana. Acta Geogr. Slov. 2016, 5, 57-73. [CrossRef]

42. Murgaš, F.; Klobučník, M. Municipalities and Regions as Good Places to Live: Index of Quality of Life in the Czech Republic. Appl. Res. Qual. Life 2014, 11, 553-570. [CrossRef]

43. Rumpel, P.; Slach, O. Is Ostrava a Shrinking City? Czech Sociol. Rev. 2012, 48, 859-878. [CrossRef]

44. Khorrami, Z.; Ye, T.; Sadatmoosavi, A.; Mirzaee, M.; Davarani, M.M.F.; Khanjani, N. The Indicators and Methods used for Measuring Urban Liveability: A Scoping Review. Research Square. 2020. Available online: https://www.researchsquare.com/ article/rs-26287/v1 (accessed on 6 September 2021).

45. Tesfazghi, E.S.; Martinez, J.A.; Verplanke, J.V. Variability of Quality of Life at Small Scales: Addis Ababa, Kirkos Sub-City. Soc. Indic. Res. 2010, 98, 73-88. [CrossRef] [PubMed]

46. Badland, H.; Roberts, R.; Butterworth, I.; Giles-Corti, B. How Liveable is Melbourne? Conceptualising and Testing Urban Liveability Indicators: Progress to Date. Available online: https:/ /www.researchgate.net/publication/274376462_How_Liveable_ is_Melbourne_Conceptualising_and_testing_urban_liveability_indicators_Progress_to_date\#fullTextFileContent (accessed on 25 August 2021).

47. Gallup. How Does the Gallup-Sharecare Well-Being Index Work? 2018. Available online: https://www.gallup.com/175196 /gallup-healthways-index-methodology.aspx (accessed on 6 September 2021).

48. Rišová, K.; Pouš, R. Urban Facilities in the Quality Of Life Research: A Case Study of Banská Bystrica City (Central Slovakia). Geogr. J. 2018, 70, 99-116. [CrossRef] 
49. The Economist Intelligence Unit. The Global Liveability Index 2021: How the Covid-19 Pandemic Affected Liveability Worldwide. 2021. Available online: EIUGlobal-liveability-index-2021.pdf (accessed on 6 September 2021).

50. The Economist. The World's Most “Liveable" Cities. 2015. Available online: https://www.economist.com/graphic-detail/2015 /08/18/the-worlds-most-liveable-cities (accessed on 6 September 2021).

51. The Economist Intelligence Unit. Global Liveability Ranking 2016. Available online: https://www.eiu.com/public/topical_ report.aspx?campaignid=Liveability2016 (accessed on 6 September 2021).

52. The Economist Intelligence Unit. The Global Liveability Report 2017. Available online: https://www.eiu.com/public/topical_ report.aspx?campaignid=Liveability17 (accessed on 6 September 2021).

53. The Economist Intelligence Unit. Global Liveability Index 2018. Available online: https://www.eiu.com/public/topical_report. aspx?campaignid=Liveability2018 (accessed on 6 September 2021).

54. The Economist Intelligence Unit. Global Liveability Index 2019. Available online: https:/ /www.eiu.com/n/the-global-liveabilityindex-2019/ (accessed on 6 September 2021).

55. Morgan, K. The exaggerated death of geography: Learning, proximity and territorial innovation systems. J. Econ. Geogr. 2004, 4 , 3-21. [CrossRef]

56. Bloom Begley, L. Survey Ranks The World's Best And Worst Cities To Live (The U.S. Did Surprisingly Well). Forbes. Available online: https: / www.forbes.com/sites/laurabegleybloom/2021/02/24/survey-ranks-the-worlds-best-and-worst-cities-to-livethe-us-did-surprisingly-well/?sh=533eb9bc3ca8 (accessed on 24 January 2021).

57. Brulé, G.; Veenhoven, R. Why Are Latin Europeans Less Happy? The Impact of Hierarchy. In Polyphonic Anthropology-Theoretical and Empirical Cross-Cultural Fieldwork; Canevacci, M., Ed.; IntechOpen: London, UK, 2012; pp. 203-216.

58. Cambridge English Dictionary. Liveability. Headword. Available online: https://dictionary.cambridge.org/dictionary/english/ liveability (accessed on 25 August 2021).

59. Vanderleeuw, J.M.; Sides, J.C. Quality of Life Amenities as Contributors to Local Economies: Views of City Managers. J. Urban Aff. 2016, 38, 661-675. [CrossRef]

60. Abbott, P.; Wallace, C.D. Social Quality: A Way to Measure the Quality of Society. Soc. Indic. Res. 2012, 108, 153-167. [CrossRef]

61. Tkáčová, H.; Pavlíková, M.; Jenisová, Z.; Maturkanič, P.; Králik, R. Social media and students' wellbeing: An empirical analysis during the covid-19 pandemic. Sustainability 2021, 13, 10442. [CrossRef]

62. Chrysopoulou, A. The Vision of a Well-Being Economy. Stanford Social Innovation Review. 2020. Available online: https: //ssir.org/articles/entry/the_vision_of_a_well_being_economy\# (accessed on 20 August 2021). 